\section{Japanese Universities Facing the World}

\section{Ruth Hayhoe}

Ruth Hayhoe is professor of higher education and associate dean, Faculty of Education, Ontario Institute for Studies in Education and University of Toronto, 252 Bloor St. West, Toronto, Ontario M5S 1V6, Canada. In 1996, she was a visiting professor of education at Nagoya University, Japan.

M any people are suggesting that the 21 st century will be the Asian century, a period when the center of the world economy moves to Asia, with Japan and China as the two economic superpowers. While there may be elements of exaggeration and even myth associated with this perception, I welcomed the opportunity provided by the Japan Foundation to spend six months on a fellowship in Japan studying the international role of Japanese universities. The central question of interest in my study was what sort of cultural role we might expect them to play in the coming century. I was also interested in understanding the barriers they were experiencing, in shifting from the task of absorbing and adapting Western knowledge to the Japanese context, to an active role in introducing Japanese and Asian knowledge approaches to the world, and exercising global cultural leadership. Why is it that Toyota and Mitsubishi are so well known around the world, while universities such as Todai and Waseda are not yet household words?

In order to explore these questions, I decided to carry out a series of interviews with three distinct groups of actors: firstly, representatives of governmental and societal agencies responsible for higher education, foreign affairs, and official development assistance; secondly, members of university international offices responsible for universities' efforts as institutions; and finally, distinguished professors, both women and men, who could speak to issues of the internationalization of scholarship. In all, I conducted more than 60 interviews, over 20 with each group, and visited 22 universities, including 10 national and public institutions, and 12 private universities.

The interviews with governmental agencies gave me a sense that the time is ripe for Japanese universities to become much more active in the international arena than they have been. Since 1991, Japan has been the world's leading donor of Overseas Development Assistance (ODA), and has moved from its initial emphasis on loans and infrastructure building to new frontiers in areas such as population and AIDS, the environment, women in development, economic liberalization, and democratization-precisely the areas where the university should have much to contribute. There were, however, at least two barriers to a greater role for the university. One lay in the fact that universities have had a strong orientation toward Europe and North America in their curricula and language teaching, while around 60 percent of the aid budget is directed to Asian countries, the rest to other developing countries. An increasing emphasis on the teaching of languages such as Chinese, Korean, Thai, and Vietnamese, as well as on Asianoriented research, is thus an important part of the university's adjustment to this new role.

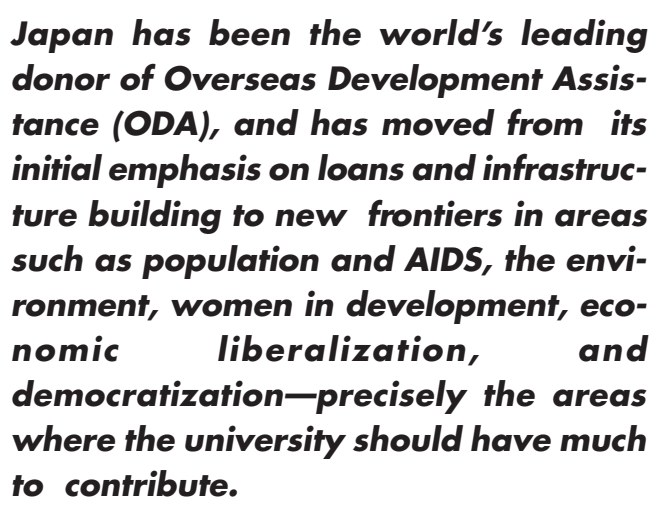

A second barrier lay in the fact that national universities are essentially an arm of the Ministry of Education, Science and Culture in their administrative arrangements, and are not able to enter into legal contracts with other parts of government, such as the Japan International Cooperation Agency (JICA), or the Overseas Economic Cooperation Fund (OECF), to design and carry out development projects. They have to find their way around the bureaucratic restrictions associated with their status. One example of how this was done came from the Faculty of Engineering at the University of Tokyo, which developed a comprehensive cooperation plan with Thailand's University of Chulalongkorn. It is to be funded by a 8.6 billion yen loan from the OECF to the Thai government.

Private universities have greater flexibility in this regard, as can be seen in a new project being planned by the Ritsumeikan University in Kyoto. The intention is to establish an Asia Pacific University in Oita prefecture, Kyshu, and strong support has already been committed by prefectural and city authorities. The purpose of the new institution is to spread information from Asia throughout the world, train personnel to be active in Asia and the world, and operate as a center for Asia Pacific Research. Negotiations are in process for support from JICA or the OECF. 
University international offices are generally enthusiastic about these new opportunities, but they face various dilemmas. One is the problem of language. In order to assist Asian students, many of whom wish to follow graduate programs, there is a need for good Japanese language programs. Western students also need Japanese language programs, but they often come for periods of a year or less, and hope for some instruction in English as well. Increasingly, there is also a demand for bilingual or English-language courses for students from developing countries coming under specially designed development assistance programs in areas such as environment, management, and taxation. These demands put tremendous stress on Japanese faculty, particularly the need for more and more courses to be taught in English or bilingually.

\section{University international offices are gen- erally enthusiastic about these new opportunities, but they face various di- lemmas.}

A second dilemma is the core question of exchange itself. The Japanese government provides generous support for international students, which has made possible a rise in numbers from 10,243 in 1983 to 53,780 in 1995 , with nearly 80 percent being from China, Taiwan, and Korea, and fully 90 percent from Asia. Much less support is available for Japanese students wishing to study abroad, and most go to North America and Europe at their own expense. However, the recent initiative to provide 1,000 "peace and friendship" scholarships per year to students from the Asia Pacific, initiated on the 50th anniversary of the end of World War II, has encouraged more universitylevel agreements with other Asian countries, and opened up new exchange opportunities for Japanese students in Asia.

Perhaps the deepest barriers to internationalism for Japanese universities lie in the character of scholarship itself, and it was this I tried to explore in the intensive interviews with scholars. What is being called for is nothing less than a complete about turn, from an approach to scholarship that focused on absorbing concepts, knowledge, and technology from more "advanced" civilizations-first China from the 7 th to the 18th centuries, then Europe and America from the Meiji Restoration of 1868 - to one that explains and projects Japanese theories, concepts, and achievements to the world.
Two obstacles were perceived as standing in the way of this change. One was a sense that in order to project themselves and their society to the world, Japanese scholars had to get to know the realities lying beneath the intellectual language made up of Chinese and European-derived concepts and construct a vocabulary for explaining Japanese society from the language of ordinary people. They felt such an effort would reveal Japan to be a society of great cultural diversity, whose peoples never fully identified with the myth of a homogenous Japanese culture or spirit. This myth had been couched in the anthropological language of European enlightenment thought, and had proven a serious international threat in the prewar period.

The second was the need for establishing fundamental relations of respect and trust with the rest of Asia. The issue of school history texts was a kind of focus for this concern, and scholars spoke of their dream of an Asian history that could be written collaboratively by colleagues from various Asian countries. Until Japanese universities fully embrace their Asian identity, they will not be ready to project themselves to the world. For their social theories to have broad relevance, they must be linked to some commonalities in Asian experience.

There is a kind of paradox here. On one side is the felt need to reconstruct an understanding of their own society and its particularity that cannot be fully conveyed in concepts imported from China or Europe. On the other side is an interest in reconnecting their society with the two great universal belief systems that came to them from China and Korea, Buddhism and Confucianism, and interpreting their social and developmental experience in the broader regional context.

\section{Perhaps the deepest barriers to inter- nationalism for Japanese universities lie in the character of scholarship itself.}

In conclusion, I would say that Japanese universities are clearly moving toward a more active international role, and that they have much to teach the world that may be extremely valuable in facilitating broad participation in the "Asian century." However, this is a new role for them, which calls for a range of adjustments in their programs and outlook, as well as a deep rethinking of core issues in Japanese scholarship. 